\title{
Environmental disclosure in the annual reports of the Russian retailers
}

\author{
Zhanna Arakelovna Kevorkova \\ Financial University under the Government of the Russian Federation, \\ Russia, Moscow \\ Irina Petrovna Komissarova \\ National Research Nuclear University MEPhI (Moscow Engineering Physics Institute) \\ Russia, Moscow \\ Albina Nikolaevna Mayorova \\ Russian State Social University, Russia, Moscow \\ Elena Aleksandrovna Mayorova \\ Alexander Fedorovich Nikishin \\ Plekhanov Russian University of Economics, Russia, Moscow
}

\section{Keywords}

Environmental disclosure, social disclosure, annual report, retail, retailer.

\begin{abstract}
The implementation of extended business environmental liability is an essential condition for sustainable development of the Russian economy, including in retail. Retailers' interest in environmental issues is related both to the enhancement of public control and to the possibility of acquiring additional competitive advantages and economic benefits. Effective environmental management aimed at achieving benefits and advantages involves disclosing of environmental information to the public. The present study focuses on environmental disclosure in the annual reports of the largest Russian retail companies. The authors conducted a content analysis of the approved annual reports for 2016 of six largest Russian retailers in terms of revenue. The article presents the results of data analysis on environmental liability in the annual reports of the largest Russian retailers; reveals the key ecological aspects of the largest Russian retailers, described in their annual reports; presents the environmental rating of the largest Russian retailers based on environmental data contained in the annual reports. The results can be used by retailers when addressing the environmental aspects of their business activity; they can also be used in further research on the topic.
\end{abstract}

Corresponding author: Zhanna Arakelovna Kevorkova

Email addresses for corresponding author: zhanna.kevorkova@bk.ru

First submission received: $10^{\text {th }}$ January 2018

Revised submission received: $21^{\text {st }}$ March 2018

Accepted: $5^{\text {th }}$ April 2018

\section{Introduction}

The technogenic type of economic development typical for modern Russian reality is characterized by high rates of consumption of non-renewable natural resources, excessive use of renewable natural resources at the rate exceeding their natural reproduction, and significant pollution of the environment with waste from industrial production and other human activities (Sinkov, Stepuk \& Martemyanova, 2015). The sustainable development of the Russian economy and ensuring social stability in the state require the inclusion of environmental issues in economic policy and forecast (Zomonova, 2016; Vinogradova, Babakaev, Larionova, Laiko \& Kobyak, 2016a).

Along with the government, public organizations and the population, business representatives also participate in addressing environmental problems. This is due both to the strengthening of state control in the environmental sphere, and the possibility of acquiring additional competitive advantages and economic benefits, including, as a result, improving the image and business reputation, increasing the company's attractiveness as an employer, reducing the amount of the resources used and the energy consumed, reducing wastes and, consequently, their disposal costs, cost-saving due to the use of recycled materials, accessibility of new markets with higher environmental standards, reducing environmental 
risks, reducing the effects of accidents, improving credit and investment attractiveness, increasing intangible assets, market capitalization and the company's value (Saldaeva, 2014; Burkaeva \& Masserov, 2015; Shevchenko, 2015; Kosyakova \& Larionov, 2016; Kurilov \& Kurilova, 2016; Vinogradova, Kulyamina, Larionova, Maloletko \& Kaurova, 2016b). Effective management of environmental activities aimed at achieving these benefits and advantages involves the disclosure of environmental data to investors, shareholders, suppliers, customers and other interested parties.

Means of the public disclosure include annual reports; social and environmental reports, corporate websites, including their news feeds; social media profiles and social media profiles, printed materials (flyers, booklets, posters) and electronic displays at sales points, as well as products and packaging. Since the concept of social-environmental responsibility is relatively new to the Russian business (compared to the Western European countries and USA) (Shevchenko, 2015), specialized environmental reports are not yet widely used by the Russian companies. Thus, the primary means of disclosure about environmental activities are the annual reports. In this regard, data contained in the annual reports turns to be more qualitative and reliable, especially when complying with the international standards (Mayorova, 2017).

Provision of environmental information in the annual reports helps to increase the transparency of business, improves the company's engagement with partners and allows to indicate the potential for growth of environmental efficiency of the economic entities (Klychova \& Gareev, 2016; Kharitonova \& Litvinov, 2007). On the other hand, the growing demand for environmental information stimulates the increasing use of an independent assessment of the companies' environmental performance based on the analysis of their public accountability (Feoktistova, Alenicheva, Dolgikh, Kopylova, Ozeryanskaya, Khonyakova, 2017).

Despite the development and improvement of the quality of an independent assessment of the environmental performance of the Russian companies in general, when examining the environmental aspects of the work of retailers (Lashkevich, 2010; Belova, 2015; Pirogova, 2015) the data presented in the annual reports was hardly used. The featured ratings, such as "Eco-Friendly Supermarket" (Recycle, 2016), "Green supermarket" (Greenpeace, 2014), also neglect the materials contained in retailers' annual reports.

In this regard, the present study analyzes the environmental data contained in the annual reports of the largest Russian retail companies. In particular, the following tasks were established: to compare data on environmental liability in the annual reports of the largest Russian retailers; to identify the main environmental aspects of their activity, presented in their annual reports; to form the environmental rating of the largest Russian retailers based on environmental data provided in the annual reports.

\section{Environmental aspects of retailers' activity}

A company's environmental activity depends on its industry sector. Trade is one of the most important, promising and dynamically developing sectors of the Russian economy, as reflected by its high share in GDP, tax revenues to the state budget, employment, large number of economic entities, including small businesses and individual entrepreneurs, as compared to other sectors (Ivanov, Mayorova \& Nikishin, 2016).

The main directions of environmental activities in retail trade are (Pirogova, 2015; Lashkevich, 2010; Belova, 2015; Bobylev \& Khodzhaev, 2007):

- logistics optimization (optimization of supply routes to retail stores, considering environmental needs and the use of modern logistics centers allow to reduce gasoline consumption and carbon dioxide emissions into the atmosphere);

- energy conservation and efficiency (the key opportunities for conservation and efficiency for retailers are related to the use of refrigeration equipment operating on refrigerants that do not destroy the ozone layer, as well as using environmentally friendly and energy-saving lamps in sales area to reduce mercury pollution; yet another promising direction is the use of renewable energy sources);

- packaging optimization (including safe disposal of packaging, avoiding the use of disposable plastic packaging in favor of reusable and environmentally friendly packaging materials; use of recycled packaging);

- reduction in paper consumption (when it comes to retailers paper consumption reduction basically means a decrease in the volume of printed advertising materials, including through increased use of electronic technologies); 
- increasing the environmental awareness of employees and customers (including by encouraging their participation in environmental actions and activities such as collecting used packaging and batteries, planting trees, ecological marathons, Earth Hour, etc., as well as selling environmentally friendly goods).

The analysis of the environmental activity of the Russian retailers is presented in thematic rankings. In 2016 in the framework of the Recycle project, the "Eco-Friendly Supermarket" rating was compiled (Recycle, 2016). The evaluation was based on 32 criteria, including the availability of paper bags, separate collection of garbage, sale of loose goods without packaging, etc. As a result, the first place was awarded to the French company Auchan, the second - to Dixy, the third - to Perekrestok (X5 Retail Group), the fourth - to ABC of taste (Azbuka vkusa), the fifth - to Billa. The largest Russian retailer Magnit is in the ninth place. In 2011-2014, Greenpeace created the "Green supermarket" rating. The criteria were: availability of disposable bags with handles at the register, sale of brand-name reusable packages and bags, commitment to wholesale purchase of goods in minimum packaging, collection of empty packaging in stores, etc. In the latest rating version (Greenpeace, 2014), the first five places were assigned to Auchan, Dixy, X5 Retail Group (Pyaterochka, Karusel, Perekrestok), Magnit and Maria-Ra, respectively.

The results show that $71.4 \%$ of the Russian retail chains pay attention to the environment in the management of corporate social responsibility (Kornilova \& Karashchuk, 2017). The retailers' environmental activity is generally positively perceived by consumers. In particular, it was revealed that, according to the Moscow region consumers, participation in environmental activities and the economical use of natural resources are more important components of retailers' corporate social responsibility than any kind of charitable activity, but less significant than the goods price and quality (Mayorova \& Lapitskaya, 2016). Nikolaeva \& Uryaseva (2016) note that consumers demonstrate a commitment to environmental goods and retailers caring for the environment. In return, retailers are interested in meeting consumers' requirements and expectations, thereby improving their environmental activity.

\section{Literature and methods}

In the study of the companies' environmental and social disclosure, the content analysis method was widely used, while annual reports were the main source of information (Dagiliene \& Gokiene, 2011; Azim \& Rahman, 2012; Ika, Dwiwinarno \& Widagdo, 2017). The source of information for analysis in the present study was the annual reports of the largest Russian retailers for 2016 (Table 1). The selected companies were included in the list of 50 largest Russian private companies, according to Forbes journal (2017); their approved annual reports for 2016 were published on their websites in open access. Magnit, X5 Retail Group, Dixy and O'Key are food retail chains and direct competitors, M.Video is a chain of stores of home appliances and electronics.

\begin{tabular}{|l|l|c|c|c|}
\hline \multicolumn{1}{|c|}{ Company } & \multicolumn{1}{|c|}{ Headquarters } & $\begin{array}{c}\text { Revenues, } \\
\text { billion rubles. }\end{array}$ & $\begin{array}{c}\text { Annual revenue change, } \\
\text { billion rubles. }\end{array}$ & Personnel \\
\hline Magnit & Moscow & $1,074.8$ & +124.2 & 270,000 \\
\hline X5 Retail Group & Krasnodar & $1,033.7$ & +224.9 & 196,128 \\
\hline Dixy & Moscow & 311.2 & +38.9 & 55,000 \\
\hline Lenta & St. Petersburg & 306.4 & +53.6 & 45,689 \\
\hline M.Video & Moscow & 183.2 & +21.5 & 14,931 \\
\hline $\mathbf{O}^{\prime}$ Key & Moscow & 175.5 & +13 & 25,000 \\
\hline
\end{tabular}

Table 1 - Key features of the largest Russian retailers in 2016 (Forbes, 2017)

At the first stage, quantitative and qualitative characteristics of environmental information presented in the annual reports of retailers were compared, including the share of the environmental section in the total volume of the report and its social and environmental section, the availability of illustrative numerical data and photographs, indication of environmental standards defining the companies' activity.

At the second stage, the authors revealed the key areas of the retailers' environmental activity stated in their annual reports. The assessment was conducted on the 12 environmental aspects identified in the GRI G4 Sustainability Reporting Guidelines (materials, energy, water, biodiversity, emissions, effluents and waste, products and services, compliance requirements, transportation, general information, 
environmental assessment of suppliers, complaint mechanisms on environmental issues) and on additional criterion "employees and population", referring to environmental education, raising environmental awareness and awareness of the companies' employees and buyers. The company was assigned relevant to one criterion or another if its report contained at least one of its aspects.

At the third stage, the authors compiled the rating of the largest Russian retailers based on environmental data provided in their annual reports. For this purpose, quantitative indicators (share of the environmental section in the report and its social and environmental part) were ranked from one to six in descending order, descriptive characteristics (specification of standards, availability of photographs and numerical data), and every environmental activity was assigned a zero rank if available and first rank if not available. Accordingly, the smaller the amount of rank - the greater environmental disclosure in the retailer's annual report. Based on the sum of ranks, the final rating was drafted.

\section{Results}

Table 2 provides basic quantitative and qualitative characteristics of environmental information contained in the annual reports of the retailers under consideration (the " + " sign indicates the presence of a parameter in the report of the company, the "-" sign indicates its absence). The analysis and comparison of retailers based on the presented parameters allowed for an overall view of the environmental activity in Russian retail trade, to examine the differences in activities of the largest Russian retailers in the environmental sphere and to rank them on that basis.

The section on social and socio-environmental aspects is present in the annual reports of all the retailers under examination, entitled: "Corporate social responsibility" (Lenta, O'Key), "Social responsibility" (M.Video), "Environmental and social aspects" (Dixy), "The main aspects of social and environmental policy" (Magnit), "Corporate, social and environmental responsibility" (X5 Retail Group). The socio-ecological section is the largest both in the number of pages and in the number of characters in Lenta's annual report.

The environmental information in one form or another is presented in the annual reports of five companies (except for O'Key). Three reports contain specific environmental sections: "Environmental responsibility" (Magnit), "Environmental care" (Lenta) and "Environmental review" (X5 Retail Group), the last of which is listed in the table of contents. In the annual reports of other retailers, environmental data are presented as a listing of specific policies or environmental projects. As for the X5 Retail Group, the environmental section occupies the largest share of both annual report and its social and environmental section. The annual reports of X5 Retail Group and Dixy contain a statement of compliance with specific environmental standards, such as Euro 5. The reports of Magnit and Lenta also contain statements about compliance with the requirements of Russian and international environmental legislation and environmental standards, but without titles. Five of the six retailers under review illustrate the information provided with numerical data (except for Magnit, which reveals the amount of energy used outside the social and environmental section of the annual report). Lenta's annual report also contains photos illustrating the corporate environmental activity; M.Video's report although not containing any direct illustrations includes links to web pages with photos and detailed information on the company's environmental activities and projects.

\begin{tabular}{|l|c|c|c|c|c|c|}
\hline Criteria for comparison & Magnit & $\begin{array}{c}\text { X5 Retail } \\
\text { Group }\end{array}$ & Dixy & Lenta & M.Video & O'Key \\
\hline Availability of the socio-environmental section & + & + & + & + & + & + \\
\hline $\begin{array}{l}\text { Share of the social and environmental section in } \\
\text { the report, \% of the total number of pages }\end{array}$ & 3.9 & 7.6 & 5.4 & 11.0 & 1.6 & 4.3 \\
\hline $\begin{array}{l}\text { Share of the social and environmental section in } \\
\text { the report, \% of the total number of words }\end{array}$ & 4.4 & 6.4 & 6.2 & 4.7 & 2.0 & 6.6 \\
\hline $\begin{array}{l}\text { Share of the social and environmental section in } \\
\text { the report, \% of the total number of characters }\end{array}$ & 4.8 & 6.5 & 6.5 & 6.9 & 2.1 & 6.6 \\
\hline Availability of environmental information & + & + & + & + & + & - \\
\hline Availability of the environmental section & + & + & - & + & - & - \\
\hline $\begin{array}{l}\text { Availability of the environmental section in the } \\
\text { table of contents }\end{array}$ & - & + & - & - & - & - \\
\hline
\end{tabular}




\begin{tabular}{|c|c|c|c|c|c|c|}
\hline $\begin{array}{l}\text { Share of the environmental section in the report, } \\
\% \text { of the total number of pages }\end{array}$ & 0.8 & 1.5 & $\mathrm{n} / \mathrm{a}$ & 1.3 & $\mathrm{n} / \mathrm{a}$ & $\mathrm{n} / \mathrm{a}$ \\
\hline $\begin{array}{l}\text { Share of the environmental section in the report, } \\
\% \text { of the total number of words }\end{array}$ & 0.9 & 1.6 & $\mathrm{n} / \mathrm{a}$ & 0.6 & $\mathrm{n} / \mathrm{a}$ & $\mathrm{n} / \mathrm{a}$ \\
\hline $\begin{array}{l}\text { Share of the environmental section in the report, } \\
\% \text { of the total number of characters }\end{array}$ & 1.0 & 1.6 & $\mathrm{n} / \mathrm{a}$ & 0.6 & $\mathrm{n} / \mathrm{a}$ & $\mathrm{n} / \mathrm{a}$ \\
\hline $\begin{array}{l}\text { Share of the environmental section in social and } \\
\text { environmental section, \% of the total number of } \\
\text { pages }\end{array}$ & 21.4 & 20.0 & $\mathrm{n} / \mathrm{a}$ & 11.8 & $\mathrm{n} / \mathrm{a}$ & $\mathrm{n} / \mathrm{a}$ \\
\hline $\begin{array}{l}\text { Share of the environmental section in social and } \\
\text { environmental section, \% of the total number of } \\
\text { words }\end{array}$ & 19.8 & 24.7 & $\mathrm{n} / \mathrm{a}$ & 12.9 & $\mathrm{n} / \mathrm{a}$ & $\mathrm{n} / \mathrm{a}$ \\
\hline $\begin{array}{l}\text { Share of the environmental section in social and } \\
\text { environmental section, \% of the total number of } \\
\text { characters }\end{array}$ & 21.3 & 24.8 & $\mathrm{n} / \mathrm{a}$ & 8.9 & $\mathrm{n} / \mathrm{a}$ & $\mathrm{n} / \mathrm{a}$ \\
\hline \begin{tabular}{|l|l|} 
Statement of compliance with specific \\
environmental standards
\end{tabular} & - & + & + & - & - & - \\
\hline Availability of confirmatory numerical data & - & + & + & + & + & - \\
\hline Availability of confirmatory photos & - & - & - & + & - & - \\
\hline
\end{tabular}

Table 2 - Comparative characteristics of environmental information in the annual reports of retailers

(compiled by the authors based on annual reports)

The analysis of the annual reports of the largest Russian retailers shows that the main aspect of their environmental activities is the work on improving the environmental awareness and consciousness of the population and employees (Figure 1). It manifests itself in providing opportunities for buyers and employees of separate collection of garbage, collection of waste paper, used batteries, etc., participation of employees in environmental events organized by third-party profile funds (for example, the "Earth Hour" organized by the World Wildlife Fund), partnership with government entities (for example, Lenta cooperates with the Committee for Nature Management, Environmental Protection and Ensuring Environmental Security of the Government of St. Petersburg), distribution of ecological products, etc. In one way or another, all the retailers that pay attention to environmental issues work with their employees and the population living in close proximity to their stores.

The annual reports of the four companies claim the lack of violations and full compliance with activities of the Russian and international environmental law and the applicable environmental standards. However, as it has been said above, retailers do not always specify the documents to which they refer. These four reports also provide information on economical energy consumption, mainly with the use of energy-saving technologies in refrigeration equipment and lighting of trade halls, as well as on reducing the volume of polyethylene consumer packaging, offering paper or reusable environmentally friendly bags to customers and other aspects of the "Products and services" criterion.

Three of the reports provide information on the reduction of emissions and waste, their safe disposal and recycling, as well as the use of secondary materials in economic activities. Two of the reports contain data on the minimum environmental impact of transport used for delivery of goods. One of the reports provides information on suppliers' compliance with high environmental requirements, on work aimed at supporting biodiversity, and on wastewater treatment in stores. Information on the amount of costs for environmental purposes is also present in one of the reports. Information on the mechanism of lodging complaints related to environmental violations, as well as to harmful emissions into the atmosphere, has not been detected in the reviewed annual reports.

The rating of the largest Russian retailers based on environmental data, presented in their annual reports, has led to the following: 1st place - X5 Retail Group, 2nd place - Magnit, 3rd place - Lenta, 4th place - Dixy, 5th place - M.Video, 6th place - O'Key. 


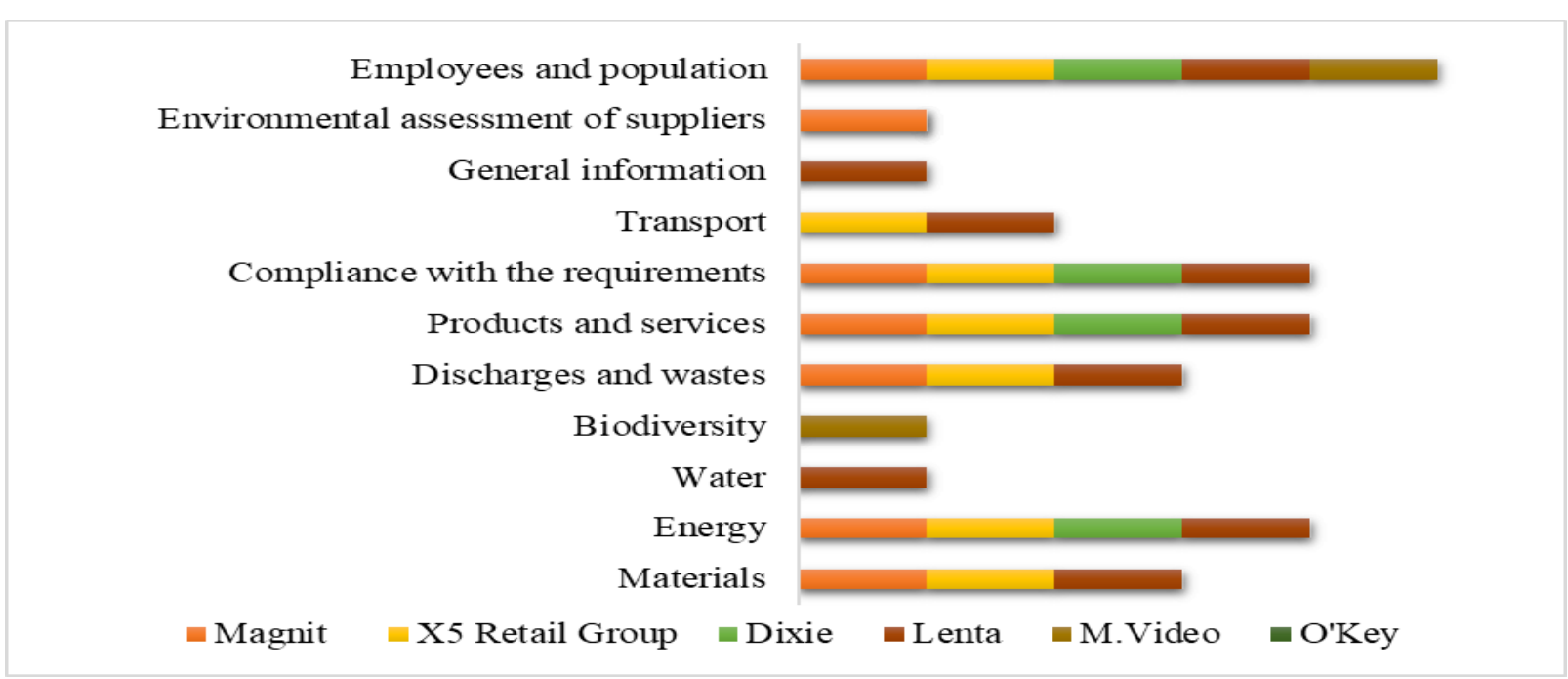

Figure 1 - Environmental aspects of the activity of the largest Russian retailers (compiled by the authors based on annual reports)

\section{Discussion and limitations}

According to the data presented in the annual reports, X5 Retail Group and Magnit are the most environmentally active retailers. They also occupy leadership positions in the market of Russia's food retailers in terms of revenue and number of employees (Forbes, 2017). The least environmentally active retailers are M.Video and O'Key, which in 2016 received the lowest revenue among the companies under survey. In the ratings compiled by Recycle (2016) and Greenpeace (2014), the leaders are Dixy and Auchan. Furthermore, the "Eco-Friendly Supermarket" rating (Recycle, 2016) notes such retailers as "Perekrestok" and "Green Perekrestok" (X5 Retail Group) - in the third place, "Pyaterochka" (X5 Retail Group) - on the sixth place, and Magnit - in the 9th place. Lenta, M.Video and O'Key have not been presented in this rating. The "Green Supermarket" rating (Greenpeace, 2014), along with Dixy also notes such retail chains as "Pyaterochka", "Karusel", "Perekrestok" (X5 Retail Group) - in the third place, Magnit - in the fourth place, Lenta - in the seventh place and O'Key - in the eighth place.

The differences in the results and ratings obtained can be related both to the methods and the period, as well as to the mismatch of the real environmental activity with the materials presented in the annual reports, which can be manifested in two directions. First, in the framework of environmental marketing, some retailers are trying to exaggerate their significance (this is the so-called "greenwashing") and secondly, on the contrary, there may be insufficient coverage of the actual environmental work in the annual report.

All these areas of retailers' environmental activities identified in the analysis, including enhancing the environmental literacy of employees and customers, energy efficiency and resource saving, safe waste management, etc., generally correspond to other studies (Belova, 2015; Lashkevich, 2010; Pirogova, 2015). Additional aspects, which have not been previously included in the study of environmental activities of the Russian retailers, are activities aimed at supporting biodiversity, and wastewater treatment in stores.

The findings are mainly limited to the companies surveyed, including their number and the lack of foreign retailers in the sample. The French retailer Auchan, which in 2016 was numerically inferior only to Magnit and X5 Retail Group in terms of revenue, ranked first in the "Green Supermarket" rating and in the "Eco-Friendly Supermarket" rating. Given that the level of social, including environmental, business liability in Russia, in general, is relatively low (Mayorova \& Lapitskaya, 2016), in further studies it is advisable to compare the disclosure of environmental information by Russian and foreign retailers and to identify examples of best practices by foreign companies. In addition, the analysis has been hampered by the fact that the presentation of information, including environmental data, significantly varies in the annual reports of different retailers. 


\section{Conclusion}

The annual reports of all major Russian retailers provide information on corporate social responsibility, and the vast majority of them - on environmental activities. Three of the surveyed annual reports contained a special section devoted to environmental data. The share of the environmental section in those reports did not exceed 1.6\%. Regarding the specification of certain environmental standards corresponding to the company's activities, illustrating numerical data and photos, the retailers under consideration do not have a unified approach. According to the annual reports, X5 Retail Group and Magnit are the most active in the environmental sphere; they are also the leaders in terms of revenue.

The work on environmental education of employees and buyers is the main environmental aspect of activities of the largest Russian retailers. The retailers also pay much attention to energy efficiency, especially in the lighting of trading rooms and refrigeration equipment, improving the environmental friendliness of goods and trade services, safe utilization and recycling of waste and the use of secondary materials, including packaging materials. Less common aspects of environmental activities in the Russian retail are the use of the most environmentally safe transport for delivery of goods, environmental assessment of suppliers, work on maintaining biodiversity and wastewater treatment in stores.

The analysis allowed the authors to draw up a detailed picture of the disclosure of environmental information in the annual reports of the Russian retailers for 2016. The results obtained can be useful for retailers paying attention to environmental aspects of their economic activities and can also be used in further scientific studies. Promising areas for further research on this topic could be a similar dynamic analysis, which will allow drawing up a conclusion about trends in the environmental performance of retailers and its disclosure in annual reports, a comparative analysis of environmental information in the annual reports of Russian and foreign retailers operating in the Russian market, strengthening of methodologies that provide quantitative assessments for environmental disclosure in annual reports, considering industry specifics, along with assessing the relationship between environmental and economic aspects of retailers' activity.

\section{References}

Azim, M.I., \& Rahman, S. (2012). Renewable Energy, Sustainability and Environment: Are We There Yet?. World Journal of Social Sciences, 2(3), 168-181.

Belova, O.Y. (2015). Ekologicheskaya sostavlyayushchaya $\mathrm{v}$ deyatelnosti torgovykh predpriyatii [Environmental Component in the Activity of Trade Enterprises]. In Ekonomika $v$ sotsiokulturnom prostranstve sovremennosti: problemy, resheniya, prognozy [Economic and Social Changes: Facts, Trends, Forecast] (p. 20). Vladimir: Transit-IKS.

Bobylev, S.N., Khodzhaev, A.S. (2007). Economics of nature management. Moscow: Infra-M.

Burkaeva, E., \& Masserov, D.A. (2015). Rol ekologicheskogo audita v povyshenii ekologicheskoi effektivnosti deyatel'nosti predpriyatiya [Role of the Environmental Audit in Improving the Environmental Enterprise Performance]. Kontentus, 12(41), 360-365.

Dagiliene, L., \& Gokiene, R. (2011). Valuation of Corporate Social Responsibility Reports. Economics and Management, $16,21-27$.

Feoktistova E. N., Alenicheva L. V., Dolgikh E. I., Kopylova G. A., Ozeryanskaya M. N., Khonyakova N. V. (2017). Analytical review of corporate non-financial reports: 2015-2016 years of output. Moscow: RSPP (Russian Union of Industrialists and Entrepreneurs).

Forbes. (2017). 200 krupneishikh chastnykh kompanii Rossii [200 Largest Russian Private Companies]. Retrieved December 15, 2017, from http://www.forbes.ru/rating/350675-200-krupneyshih-rossiyskih-kompaniy-2017\#all_rating

Greenpeace. (2014). Reiting "Zelenyi supermarket" ["Green Supermarket" Rating]. Retrieved December 15, 2017, from http://www.greenpeace.org/russia/ru/campaigns/waste/greensupermarket/rating/2014may-v5/

Ika, S.R., Dwiwinarno, T., \& Widagdo, A.K. (2017). Corporate Social Responsibility and Corporate Governance in Indonesian Public Listed Companies. SHS Web Conf., 34, 13002.

Ivanov, G.G., Mayorova, E.A., \& Nikishin, A.F. (2016). Social Trading Performance in Russian Regions. International Journal of Economic Research, 13(9), 3991-3999.

Kharitonova E.N., Litvinov I.A. (2007). In relation to reflection of economic, environmental and social performance of organization in its public recording. Advances in current natural sciences, 1, 109.

Klychova G.S., Gareev R.I. (2016). Economic analysis of relative eco-efficiency indicators of the enterprise, Accounting in Budgetary and Non-Profit Organizations, 18(402), 40-43.

Kornilova, O., \& Karashchuk, O. (2017). Socially responsible business in trade: further development in Ukraine and Russia. Problems and Perspectives in Management, 15(3), 445-452. 
Kosyakova, I.V., \& Larionov, I.V. (2016). Formirovanie strategii upravleniya krupnym promyshlennym predpriyatiem, napravlennoi na ekologicheskuyu otvetstvennost biznesa [Formation of a Management Strategy of a Large Industrial Enterprise Aimed at Environmental Responsibility of Business]. Ekonomické trendy, 3, 9-12.

Kurilov, K.Yu., \& Kurilova, A.A. (2016). The Issue of Valuation. Karelian Scientific Journal, 5(4(17)), 149-152.

Lashkevich, N.M. (2010). Napravleniya ekologizatsii roznichnoi torgovli [Directions of the Retail Greening]. Nauchnoe obozrenie, 4, 76-78.

Mayorova, E.A., \& Lapitskaya, N.V. (2016). Assessment of Customers' Perception of Social Responsibility of Trade Business. International Journal of Economics and Financial Issues, 6(2), 158-163.

Mayorova, A.N. (2017). Means of corporate social responsibility disclosure. Azimuth of Scientific Research: Economics and Administration, 4 (21), 175-178.

Nikolaeva, T.I., \& Uryaseva, T.I. (2016). Progressivnye tekhnologii snizheniya raskhodov torgovogo predpriyatiya i zashchity okruzhayushchei sredy [Innovative Technologies to Reduce Costs of a Trade Enterprise and Protect the Environment]. Sovremennaya nauka: tendentsii razvitiya, 12, 144-148.

Pirogova, O.E. (2015). Ekologicheskie aspekty ustoichivogo razvitiya v deyatelnosti torgovykh predpriyatii [Environmental Aspects of Sustainable Development in the Activities of Commercial Enterprises]. Tekhnikotekhnologicheskie problemy servisa, 2(32), 84-87.

Recycle. (2016). Ekologichnyi supermarket 2016 [Eco-Friendly Supermarket 2016]. Retrieved December 15, 2017, from http:/ / recyclemag.ru/ekologichnyiy-supermarket-2016

Saldaeva, M.N. (2014). Ekologicheskaya otvetstvennost biznesa i konkurentosposobnost: vozmozhen li vzaimno usilivayushchiisya effekt? [Corporate Environmental Liability and Competitiveness: Is the Mutually Reinforcing Effect Possible?]. Vestnik Samarskogo gosudarstvennogo ekonomicheskogo universiteta, 6(116), 68-71.

Shevchenko, I.L. (2015). Ekologicheskaya otvetstvennost v praktike korporativnogo upravleniya krupneishikh rossiiskikh kompanii [Environmental Liability in the Practice of Corporate Governance of the Largest Russian Companies]. Vestnik Kuzbasskogo gosudarstvennogo tekhnicheskogo universiteta, 5(111), 190-197.

Sinkov, L.S., Stepuk, E.I., \& Martemyanova, A.N. (2015). Ekologicheskaya i sotsialnaya otvetstvennost gornykh predpriyatii kak klyuchevoe zveno ikh ustoichivogo razvitiya [Environmental and Social Responsibility of Mining Enterprises as a Key Link in Their Sustainable Development]. Gornyi informatsionno-analiticheskii byulleten, 40, 116-127.

Vinogradova, M.V., Babakaev, S.V., Larionova, A.A., Laiko, M.Yu., \& Kobyak, M.V. (2016a). Modernization of Management: Social and Socio-Cultural Aspects. International Journal of Environmental and Science Education, 11(15), 7847-7856.

Vinogradova, M.V., Kulyamina, O.S., Larionova, A.A., Maloletko, A.N., \& Kaurova, O.V. (2016b). The Use of Management of Objectives Method of Attraction and Evaluation of Effectiveness of Investments to the Tourism and Hospitality. International Review of Management and Marketing, 6(S2), 241-246.

Zomonova, E.M. (2016). Definition and Principles of the "Green Economy". Azimuth of Scientific Research: Economics and Administration, 5(14), 13-17. 